\title{
Antioxidation and Antiglycation Properties of Bunium Bulbocastanum Fruits Various Fractions and its Possible Role in Reducing Diabetes Complication and Ageing
}

\author{
Haroon Ahmad ${ }^{1 *}$, Ibrar Khan² and Wagma Nisar ${ }^{2}$
}

${ }^{1}$ Institute of Molecular Biosciences, University of Queensland, Australia

${ }^{2}$ Centre of Biotechnology and Microbiology, University of Peshawar, KhyberPukhtoon Khwa, Pakistan

\begin{abstract}
Over the centuries medicinal plants have benefited mankind against different diseases. Advanced Glycation End-products (AGE's) formation due to non-enzymatic glycation and oxidative stress has been demonstrated in the pathogenesis of diabetic complications and aging processes. In this study we investigated the antiglycation and antioxidation potential of different fraction Bunium bulbocastanum fruits. Our results indicated that the chloroform fraction of $B$. bulbocastanum fruits had more antiglycation ability with a Minimum inhibitory concentration $\left(\mathrm{MIC}_{50}\right)$ of $132.88 \mu \mathrm{g} / \mathrm{ml}$ as compared to the $\mathrm{MIC}_{50}$ of $189.92,199.08,202.50$ and $261.41 \mu \mathrm{g} / \mathrm{ml}$ of aqueous, crude methanolic, ethyl acetate and $n$-hexane fractions, respectively. While the results of antioxidation assay showed that Ethyl acetate has more antioxidation potential than the standard (ascorbic acid). Ethyl acetate, aqueous, crude methanolic, n-hexane and chloroform fractions had $31.24,26.07,20.67,15.51$ and $5.72 \%$ antioxidation potential at $0.5 \mathrm{mg} / \mathrm{ml}$ respectively.
\end{abstract}

Keywords: AGE's; Antiglycation; Antioxidation; Bunium bulbocastanum

\section{Introduction}

Generation of free radicals inside human body takes place from both endogenous and exogenous sources [1]. Endogenous include oxidative enzymes and respiratory chain while exogenous include smoking and other air pollutants [1]. These sources create overproduction of free radicals which ultimately potentiate development of various diseases because of oxidative stress [1-3]. Some of the destructive effects of oxidative stress include damaged proteins, nucleic acid and lipids which lead to conditions like diabetes, Alzheimer's, cancer, cardiovascular diseases [1-3].

This oxidative stress is also an instrumental factor in glycation process [4]. Glycation is basically a reaction of amino groups in amino acid of proteins and carbonyl group in sugar resulting in formation of Amadori products [5-7]. These intermediate Amadori products then through a series of reactions; including oxidation reactions, ultimately forms advanced glycation end products (AGE's) [5-7]. These AGE's are very dangerous to our health and cause most of diabetic mellitus complications and result in speeding up of ageing process [7-10]. From pathogenesis point of view AGE's accumulation is hazardous to our body cells and results in acceleration of aging and diabetic complications including retinopathy, cataract, neuropathy and atherosclerosis [11]. Hence any source that has both antioxidation and antiglycation capabilities can be very helpful against such disease conditions.

B. bulbocastanum is found primarily in northern India, Kashmir, Afghanistan, Tajikistan and Persia [12]. B. bulbocastanum has been used for edible purposes for years. Its seeds can be used either in raw or cooked form to enhance food flavors or to improve its taste [12]. Medicinally it is also used as an astringent [12]. Keeping in view the novelty of $B$. bulbocastanum, the current study was aimed to screen the fruits of $B$. bulbocastanum for possible antioxidation and antiglycation potential.

\section{Materials and Methods}

\section{Plant material}

Fruits of B. bulbocastanum plants were collected from Kashmir and kindly identified by Prof. Dr. Abdur- Rasheed, Plant taxonomist, Department of Botany, University of Peshawar, Khyber Pukhtunkhwa, Pakistan.

\section{Extraction}

The B. bulbocastanum fruits were kept in shade for drying and were then chopped and grounded to powder. The powdered materials were soaked in methanol (twice) for 15 days at room temperature. Each time the filtrate was filtered and the filtrates were combined and concentrated to crude methanolic extracts using rotatory evaporator at $40^{\circ} \mathrm{C}$.

\section{Fractionation}

The crude methanolic extract of B. bulbocastanum fruits (137 g) was suspended in distilled water $(350 \mathrm{ml})$. It was further partitioned with $n$-hexane $(3 \times 500 \mathrm{ml})$, chloroform $(3 \times 500 \mathrm{ml})$ and ethyl acetate $(3 \times 500 \mathrm{ml})$, respectively, to yield the $n$ - hexane $(44 \mathrm{~g})$, chloroform (29 $\mathrm{g})$, ethyl acetate $(15 \mathrm{~g})$ and aqueous $(36 \mathrm{~g})$ fractions. $20 \mathrm{~g}$ of the crude methanolic extract of was left for biological/pharmacological activities. All the fractions will only contain particular compounds based on the solubility of these compounds from the crude extract. For instance, the $n$ - hexane fraction will contain only those compounds which are nonpolar and soluble in non-polar solvents and so on.

\section{Materials}

The materials used for in vitro antiglycation assay were: Bovine Serum Albumin (BSA), D-glucose, Sodium dihydrogen phosphate $\left(\mathrm{Na}_{2} \mathrm{HPO}_{4}\right)$, Potassium dihydrogen phoshpate $\left(\mathrm{KH}_{2} \mathrm{PO}_{4}\right)$, Sodium

*Corresponding author: Haroon Ahmad, Institute of Molecular Biosciences, University of Queensland, Australia, Tel: 92-3339342222; E-mail: haroon29@gmail.com

Received January 14, 2014; Accepted February 19, 2014; Published February 26, 2014

Citation: Ahmad H, Khan I, Nisar W (2014) Antioxidation and Antiglycation Properties of Bunium Bulbocastanum Fruits Various Fractions and its Possible Role in Reducing Diabetes Complication and Ageing. Vitam Miner 3: 118.

Copyright: (c) 2014 Ahmad H, et al. This is an open-access article distributed under the terms of the Creative Commons Attribution License, which permits unrestricted use, distribution, and reproduction in any medium, provided the original author and source are credited. 
Citation: Ahmad H, Khan I, Nisar W (2014) Antioxidation and Antiglycation Properties of Bunium Bulbocastanum Fruits Various Fractions and its Possible Role in Reducing Diabetes Complication and Ageing. Vitam Miner 3: 118.

Chloride ( $\mathrm{NaCl})$, Potassium Chloride (KCl), Aminoguanidine (Merck, Pakistan), Retinoid (Merck, Pakistan) and Tri-Chloro Acetic Acid (TCA) (Sigma, Pakistan). While alkaline PBS (137 nM NaCl, $8.1 \mathrm{nM}$ $\mathrm{Na}_{2} \mathrm{HPO}_{4} 2.68 \mathrm{mM} \mathrm{KCl}, 1.47 \mathrm{mM} \mathrm{KH}_{2} \mathrm{PO}_{4}$ ) was prepared and its $\mathrm{pH}$ adjusted to 7.4 with $0.25 \mathrm{~N} \mathrm{NaOH}$.

The materials used for Nitric Oxide (NO) free radical scavenging assay were: Sodium Nitroprusside $\left(\mathrm{Na}_{2}\left[\mathrm{Fe}(\mathrm{CN})_{5} \mathrm{NO}\right] \cdot 2 \mathrm{H}_{2} \mathrm{O}\right)(\mathrm{SNP})$, Sulphanilic acid (SA) $(0.33 \%$ in $20 \%$ Acetic acid), [N-(1-Napthyl) Ethylene diamine Dihydrochloride] (NED) $\left(0.1 \%\right.$ in $\left.\mathrm{H}_{2} \mathrm{O}\right)$, Phosphate buffer $(10 \mathrm{mM}, \mathrm{pH}=7.4)$, UV double beam spectrophotometer, micropipettes, test samples (crude methanolic extract), Methanol (as blank) and Ascorbic Acid (Vitamin-C) as positive control.

\section{In vitro glycation assay}

The method of Matsuura et al. [13] was followed with little modifications. Stock solutions of the plant extracts were prepared by dissolving $3 \mathrm{mg}$ in $1 \mathrm{ml}$ of alkaline PBS. From the stock solution 10, 50, 90, and $130 \mu \mathrm{L}$ solutions were taken using micropipette and were mixed with a solution containing $400 \mu \mathrm{g}$ BSA and $200 \mathrm{mM}$ glucose. These reaction mixtures were kept in a water bath at $55^{\circ} \mathrm{C}$ for 48 hours. BSA and glucose without any inhibitor was used as control. After the incubation time the reaction mixture was transferred into separate Effendorf tubes and $10 \mu \mathrm{L}$ of $100 \% \mathrm{w} / \mathrm{v}$ TCA was added and centrifuged at $14500 \mathrm{rpm}$ at $4^{\circ} \mathrm{C}$ for 4 minutes. Supernatant then discarded and the pellet was re-dissolved in $400 \mu \mathrm{L}$ alkaline PBS.

Using fully automated UV double beam spectrophotometer, the degree of absorbance for both the control and the test reaction mixtures were taken at $350 \mathrm{~nm}$. Percent inhibition was calculated using the following formula:

Percent inhibition $=\left[1-\left(\mathrm{A}_{\mathrm{s}}-\mathrm{A}_{\mathrm{o}}\right) /\left(\mathrm{A}_{\mathrm{b}}-\mathrm{A}_{\mathrm{o}}\right)\right] \times 100$

Where $A_{s}$ is absorbance of test samples, $A_{b}$ is absorbance of reaction mixture without plant extract and $\mathrm{A}_{\mathrm{o}}$ is absorbance of blank control.

\section{Nitric Oxide (NO) free radical scavenging assay}

To perform NO free radical scavenging assay the method of Ebrahimzadeh et al. [14] was followed. Stock solutions of test samples were prepared by dissolving $3 \mathrm{mg}$ of the test samples in $1 \mathrm{ml}$ of methanol. Different dilutions i.e. $0.5,0.25$ and $0.125 \mathrm{mg} / \mathrm{ml}$ of test sample were made from the stock solution and $1 \mathrm{ml}$ of each dilution was introduced into separate test tubes along with $1 \mathrm{ml}$ of SNP to make the reaction mixture. This mixture was then incubated for 90 minutes at $27^{\circ} \mathrm{C}$. After incubation $0.5 \mathrm{ml}$ of the reaction mixture was added to $1 \mathrm{ml}$ of SA and incubated at $27^{\circ} \mathrm{C}$ for 5 minutes. Add $1 \mathrm{ml}$ of NED to it and again incubate for 30 minutes at $27^{\circ} \mathrm{C}$.

Results were obtained by taking absorbance at $546 \mathrm{~nm}$. Methanol and Vitamin $\mathrm{C}$ were used as blank and positive control respectively. Percentage antioxidation potential was calculated by the following formula:

Percent inhibition $=\left[\mathrm{A}_{\mathrm{o}}-\mathrm{A}_{\mathrm{t}} / \mathrm{A}_{\mathrm{o}}\right] \times 100$

Where $A_{o}$ is absorbance of control; reaction mixture without extract, $A_{t}$ absorbance of test samples.

\section{Results}

\section{Antiglycation assay}

The UV double beam spectrophotometric analyses of the reaction and test mixtures of $B$. bulbocastanum fruits are shown in the Figure 1. It can be seen from the figure that as the concentration of the $B$. bulbocastanum fruits extract increases from $10 \mu \mathrm{g} / \mathrm{mL}$ to $390 \mu \mathrm{g} / \mathrm{mL}$ the absorbance decrease indicating an increase in antiglycation ability of that fraction. However the relatively slow decrease from $30 \mu \mathrm{g} / \mathrm{mL}$ onwards is attributed to the effect of interfering color agents present in B. bulbocastanum fruits fractions.

The minimum inhibitory concentrations $\left(\mathrm{MIC}_{50}\right)$ of aminoguanidine and $B$. bulbocastanum fruit fractions were also calculated. We found that the $\mathrm{MIC}_{50}$ of aminoguanidine, crude methanolic, $n$-hexane, chloroform, ethyl acetate and aqueous extracts were $70.14,199.08,261.41,132.88,202.50,189.92 \mu \mathrm{g} / \mathrm{ml}$, respectively. These values can also be inferred from Figure 1. Figure 2 shows the percent inhibition of Millard reaction by aminoguanidine and $B$. bulbocastanum fruit fractions verses the amount of test sample used i.e. Sample concentration. Hence from the $\mathrm{MIC}_{50}$ and both Figures 1 and 2 it is confirmed that the chloroform fraction had most appreciable antiglycation ability with $\mathrm{MIC}_{50}$ of $132.88 \mu \mathrm{g} / \mathrm{ml}$ while the $n$-hexane had least antiglycation potential with $\mathrm{MIC}_{50}$ of $261.41 \mu \mathrm{g} / \mathrm{ml}$.

\section{NO free radical scavenging Assay}

The antioxidation potential of B. bulbocastanum fruits fractions at different concentrations was compared with ascorbic acid (Vitamin-C) as standard. Results obtained from NO scavenging assay are shown in Table 1. It can be seen from the table that among the different fractions of B. bulbocastanum ethyl acetate fraction had more potential of antioxidation and even exceeds the antioxidation potential (31.24\%)

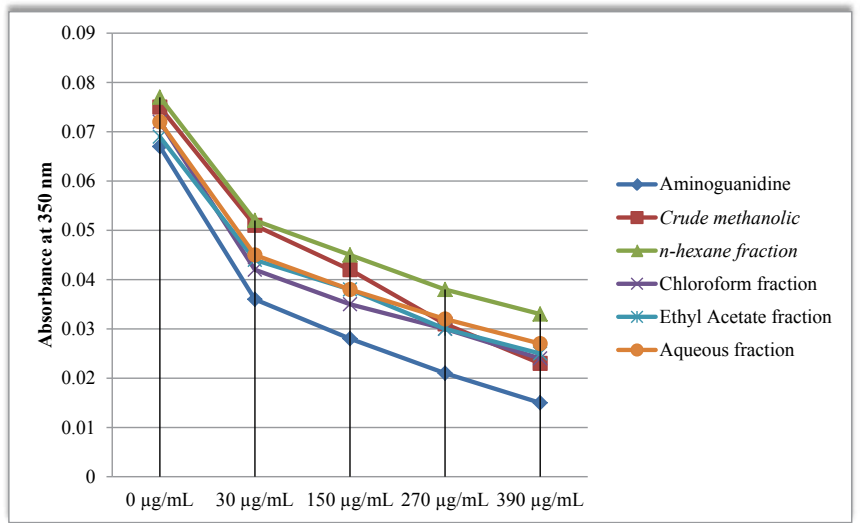

Figure 1: Antiglycation properties of $B$. bulbocastanum fruits fractions at different concentrations.

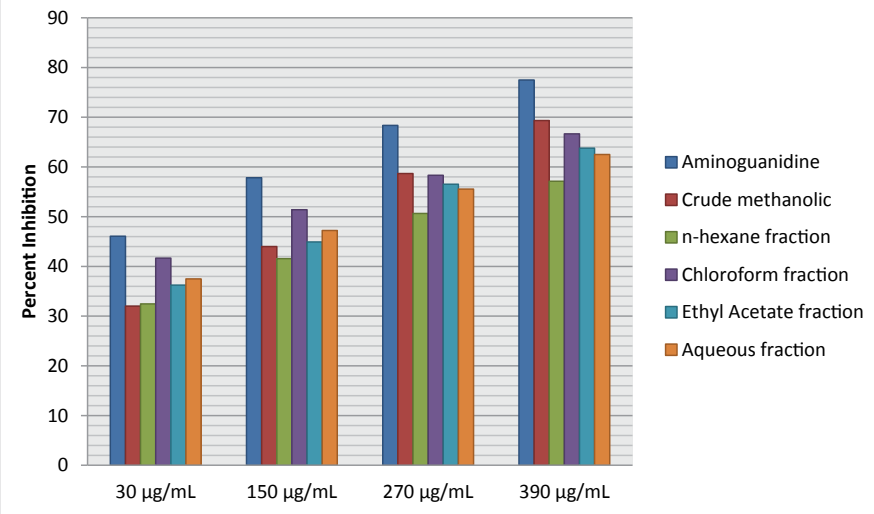

Figure 2: Percentage inhibition of $B$. bulbocastanum fruits fractions at different concentrations. 
Citation: Ahmad H, Khan I, Nisar W (2014) Antioxidation and Antiglycation Properties of Bunium Bulbocastanum Fruits Various Fractions and its Possible Role in Reducing Diabetes Complication and Ageing. Vitam Miner 3: 118.

\begin{tabular}{|c|c|c|c|}
\hline \multirow{2}{*}{ Test Sample } & \multicolumn{3}{|c|}{ Percent antioxidation activity } \\
\hline Ascorbic Acid & $\mathbf{0 . 5 m g / m l}$ & $\mathbf{0 . 2 5} \mathbf{m g} / \mathbf{m l}$ & $\mathbf{0 . 1 2 5} \mathbf{m g} / \mathbf{m l}$ \\
\hline Crude methanolic extract & 26.50 & 26.28 & 24.34 \\
\hline$n$-hexane fraction & 20.67 & 17.38 & 11.84 \\
\hline Chloroform fraction & 15.51 & 14.92 & 8.32 \\
\hline Ethyl acetate fraction & 5.72 & 5.24 & 4.58 \\
\hline Aqueous fraction & 31.24 & 24.89 & 21.66 \\
\hline
\end{tabular}

Table 1: Percent antioxidation activity of $B$. bulbocastanum fruits fractions at 0.5 , 0.25 and $0.125 \mathrm{mg} / \mathrm{ml}$ concentration.

of the standard (26.50) at $0.5 \mathrm{mg} / \mathrm{ml}$ concentration. Aqueous fraction also showed significant antioxidation potential of $26.07 \%$ at $0.5 \mathrm{mg} /$ $\mathrm{ml}$ concentration. However the rest of the three fractions had lower antioxidation activity from the standard at all the concentration.

\section{Discussion}

As far as we had investigated there have been no antiglycation and antioxidation studies on B. bulbocastanum fruits. This study is the first one that reports that its fractions do have antiglycation and antioxidation potentials. Our findings for the antiglycation in vitro assay showed that among the test samples chloroform fraction was the most effective antiglycation agent with $\mathrm{MIC}_{50}$ of $132.88 \mu \mathrm{g} / \mathrm{ml}$ followed. We also found that the percent inhibition of glycation is concentration dependent.

Our result for the NO free radical scavenging assay shows that as the concentration of test samples increases the percent antioxidation potential increases. Therefore indicating concentration dependence of antioxidation ability in both the standard and test samples. In our study we found that all fractions of $B$. bulbocastanum had antioxidation potential. The percent antioxidation inhibition of 31.24 and $26.07 \%$ at $0.5 \mathrm{mg} / \mathrm{ml}$ for ethyl acetate fraction and aqueous fraction presents an encouraging finding. However in particular the ethyl acetate fraction antioxidation ability of $31.24 \%$ as compared to the standard (Ascorbic acid) value of $26.50 \%$ represents its possible therapeutic use as antioxidant.

Chloroform fraction of $B$. bulbocastanum fruits could be used as antiglycation agent in therapeutics. While the ethyl acetate and aqueous fraction of $B$. bulbocastanum fruits can be used as therapeutic agents against harmful oxidation reactions. Therefore we conclude that further studies on B. bulbocastanum fruits extracts could lead to therapeutics for reducing diabetic complications and process of ageing.

\section{References}

1. Young IS, Woodside JV (2001) Antioxidants in health and disease. J Clin Pathol 54: 176-186.

2. Barnham KJ, Masters CL, Bush Al (2004) Neurodegenerative diseases and oxidative stress. Nat Rev Drug Discov 3: 205-214.

3. Rahimi R, Nikfar S, Larijani B, Abdollahi M (2005) A review on the role of antioxidants in the management of diabetes and its complications. Biomed Pharmacother 59: 365-373.

4. Hunt JV, Bottoms MA, Mitchinson MJ (1993) Oxidative alterations in the experimental glycation model of diabetes mellitus are due to protein-glucose adduct oxidation. Some fundamental differences in proposed mechanisms of glucose oxidation and oxidant production. Biochem J $291: 529-535$.

5. Al-Abed Y, Bucala R (2000) Structure of a synthetic glucose derived advanced glycation end product that is immunologically cross-reactive with its naturally occurring counterparts. Bioconjug Chem 11: 39-45.

6. Rojas A, Morales MA (2004) Advanced glycation and endothelial functions: a link towards vascular complications in diabetes. Life Sci 76: 715-730.

7. Wu CH, Yen GC (2005) Inhibitory effect of naturally occurring flavonoids on the formation of advanced glycation endproducts. J Agric Food Chem 53: 31673173.

8. Baral N, Koner BC, Karki P, Ramprasad C, Lamsal M, et al. (2000) Evaluation of new WHO diagnostic criteria for diabetes on the prevalence of abnormal glucose tolerance in heterogeneous Nepali population: The implication of measuring glycated hemoglobin. Singapore Medical Journal 41: 264-267.

9. Parija M, Bobby Z, Kumar V, Saradha B (2005) Oxidative stress and protein glycation in patients with chronic obstructive pulmonary disease. Indian J Physiol Pharmacol 49: 95-98.

10. Selvaraj N, Bobby Z, Das AK, Ramesh R, Koner BC (2002) An evaluation of level of oxidative stress and protein glycation in nondiabetic undialyzed chronic renal failure patients. Clin Chim Acta 324: 45-50.

11. Ahmed N (2005) Advanced glycation endproducts--role in pathology of diabetic complications. Diabetes Res Clin Pract 67: 3-21.

12. Clapham, Tootin, Warburg (1962) Flora of the British Isles. Cambridge University Press, UK.

13. Matsuura N, Aradate T, Sasaki C, Kojima H, Ohara, et al. (2002) Screening system for the maillard reaction inhibitor from natural product extracts. $\mathrm{J}$ Health Sci 48: 520- 526 .

14. Ebrahimzadeh MA, Nabavi SF, Nabavi SM (2009) Antioxidant activities of methanol extract of Sambucus ebulus L. flower. Pak J Biol Sci 12: 447-450. 